\title{
Marcas do Desterro. Moçambicanos deportados para São Tomé e Príncipe (1947-1961): história, estórias, atualidade ${ }^{1}$
}

\begin{abstract}
Resumo
Durante o colonialismo português, centenas de pessoas foram deportadas das colónias lusitanas africanas para São Tomé e Príncipe. A partir do século XIX, com a inserção de Portugal na economia internacional como país fornecedor de matéria-prima, periférico e dependente, a modalidade de abastecimento humano da colónia de produção de São Tomé e Príncipe ocorreu mediante o trabalho forçado, formalmente alternativo à escravatura, que já não era permitida. $O$ artigo aqui apresentado pretende ilustrar os mecanismos que fizeram com que esta migração forçada se tornasse possível, até ao início dos anos sessenta do século $\mathrm{XX}$, concentrando a análise no caso moçambicano. A pesquisa adotou uma abordagem histórica, na primeira parte, e uma antropológica e etnográfica na segunda, com entrevistas junto a alguns dos antigos trabalhadores moçambicanos deportados em São Tomé e Príncipe, a alguns repatriados em Moçambique e a testemunhas-chave dos dois lados. A investigação revelou uma realidade histórica - a do desterro - ainda muito pouco conhecida, juntamente com uma situação atual ignorada por parte quer do Estado moçambicano, quer do português. Este último ainda não assumiu a responsabilidade histórica das graves violações dos direitos humanos mais básicos destes deportados, ao passo que o primeiro nada fez, até agora, para aliviar a condição existencial destes seus cidadãos, hoje muito velhos e pobres e completamente dependentes da assistência humanitária.
\end{abstract}

Palavras-chave: Colonialismo. Trabalho forçado. Independência. Abandono.

\author{
Luca Bussotti \\ Doutor em Sociologia do \\ Desenvolvimento pela Università degli \\ Studi di Pisa, Itália. Investigador do \\ Centro de Estudos Internacionais - \\ ISCTE/Instituto Universitário de Lisboa. \\ Lisboa - PORTUGAL \\ Professor Visitante do Instituto de \\ Estudos Africanos UFPE \\ Recife-BRASIL \\ labronicus@gmail.com \\ orcid.org/0000-0002-1720-3571
}

\section{Teodora Martins}

Mestre em Direitos Humanos, Desenvolvimento Econômico e Boa Governação pela Universidade Técnica de Moçambique. Doutoranda em Paz,

Democracia, Movimentos Sociais e

Desenvolvimento Humano pela Universidade Técnica de Moçambique. MOÇAMBIQUE

teodoramartins@hotmail.com orcid.org/0000-0002-4293-4472

\section{Para citar este artigo:}

BUSSOTTI, Luca; MARTINS, Teodora. Marcas do Desterro. Moçambicanos deportados para São Tomé e Príncipe (1947-1961): história, estórias, atualidade. Tempo e Argumento, Florianópolis, v. 11, n. 27, p. 8 - 42, maio/ago. 2019.

DOI: $10.5965 / 2175180311272019008$

http://dx.doi.org/10.5965/2175180311272019008

\footnotetext{
${ }^{1}$ Nesse artigo optou-se por manter a grafia da língua nativa (Língua Portuguesa - Portugal)
} 


\title{
Deportation Marks. Mozambicans deported to Sao Tome and Principe (1947-1961): history, stories, present time
}

\begin{abstract}
During the Portuguese colonialism, hundreds of people were deported from the African Lusitanian colonies to São Tomé and Príncipe. Starting from the $19^{\text {th }}$ century, with the insertion of Portugal into the international economy as a country which provided raw materials, peripheral and dependent, the way of human supply of the productive colony of São Tomé and Príncipe occurred through the forced work, formally alternative to the slavery, which was no longer allowed. The article here presented aims at illustrating the mechanisms which got this forced migration possible, until the beginning of the Sixties of the $20^{\text {th }}$ century, concentring the analysis on the Mozambican case. The research adopted a historical approach in its first part, and an anthropological and ethnographic approach in the second one, with interviews to some of the former Mozambican workers deported to São Tomé and Príncipe, to some repatriated former workers in Mozambique e to privileged witnesses from the Mozambican and the São Tomé side. The research revealed a historical reality - the "desterro" - yet little known, together with a current situation ignored as by the Mozambican State, as by the Portuguese State. The latter did not assume the historical responsibility for the serious violations of the most basic human rights of these deported, meanwhile Mozambican government did not carry out any action, to date, to alleviate the existential condition of this group of their citizens, today very old and poor and completely dependent from the humanitarian assistance.
\end{abstract}

Keywords: Colonialism. Forced Labour. Independence. Loneliness. 


\section{Introdução}

O presente trabalho visa preencher as graves lacunas que existem na literatura especializada sobre a deportação de Moçambicanos para São Tomé e Príncipe. Os períodos aqui considerados se referem a última vaga de deportação, entre 1948 e 1961, e à época subsequente à obtenção da independência nacional de Moçambique, em 1975. A pesquisa visava inicialmente responder a uma simples inquietação por assim dizer “particular”: a de uma mãe moçambicana deportada para São Tomé e Príncipe e separada do seu filho há 49 anos. Desprovida de meios para procurá-lo por causa da idade e distância, resolveu pedir ajuda a uma das autoras da pesquisa, originária de São Tomé e Príncipe e residente há mutos anos em Moçambique, quando a senhora soube da ida dela a São Tomé e Príncipe. Através deste fato, foi possível chegar à história dos deportados, que ainda estão vivos, e seus descendentes, resgatando parte deste passado para melhor compreender as grandes injustiças que primeiro o Estado colonial português, depois o Estado moçambicano e ainda o Estado português democrático protagonizaram contra essas pessoas, até hoje quase que completamente negligenciadas por parte das autoridades públicas.

Em princípio, qualquer indivíduo que tenha sido deportado, como aconteceu no período colonial, no fim do cumprimento da (suposta) pena deve ter regressado à terra donde foi tirado de forma forçada. Mas o que aconteceu foi o inverso, o que justifica a presença deste grupo de pessoas nestas ilhas. Elas foram deportadas, escravizadas, embora com um contrato formal de trabalho, e agora vivem na miséria e abandono. Presas ao próprio passado, nunca tiveram outras escolhas a não ser a morte na terra do sofrimento, distante das suas origens.

Durante a realização desta pesquisa não foram encontrados trabalhos sobre o assunto na perspetiva que propomos, ou seja, usando as ferramentas da pesquisa histórica misturada com a de cunho antropológico e etnográfico, muito menos sobre a situação atual desta população. Neste sentido, o assunto é de suma importância por se tratar de um problema que é pouco conhecido e que envolve questões relativas à violação dos direitos humanos, sob várias perspetivas. 
Por isso os autores acreditam que a realização deste trabalho tenha uma relevância histórico-social, cultural e pessoal. No âmbito histórico-social, com o resgate desta história, estará mais evidente como a memória de fatos tão graves mas ao mesmo tempo tão relevantes no contexto da época irá voltar à tona, abrindo novas pistas de investigação. Além disso, este trabalho poderá contribuir para o resgate e afirmação identitária das sociedades envolvidas, demonstrando assim a sua relevância cultural. No âmbito pessoal, a pesquisa não parou na dimensão meramente científico-gnosiológica, uma vez que - graças a pequenos fundos disponibilizados pela Cooperação Suíça - foi possível concretizar o sonho de uma das vítimas deste processo, que conseguiu reencontrar seu filho depois de 49 anos.

A pesquisa procurou responder a algumas questões fundamentais: como é que os moçambicanos atualmente residentes em São Tomé e Príncipe foram "contratados" na altura colonial? Como é que eles hoje vivem? Qual foi a intervenção por parte dos vários Estados envolvidos no desterro ao longo das diferentes épocas? Quais as suas ações, responsabilidades, omissões? A multiplicidade de questões abordadas envolveu vários atores e seus complexos relacionamentos. Por isso, a metodologia adotada teve de considerar este vasto leque de protagonistas, com o intuito de garantir a diversificação das fontes e a compreensão do ponto de vista de todos os sujeitos desta história ainda pouco conhecida. O princípio de diversificar as fontes das testemunhas diretas individuais enquadra-se na necessidade de submeter tais fontes a um escrutínio mais rigoroso, "por cruzamento de informações obtidas a partir de fontes diferentes" (POLLACK, 1992, p. 209).

Para que isso se efetivasse foi necessário, acima de tudo, procurar os protagonistas principais, os deportados e os retornados. Para os retornados, usou-se o programa regional da Rádio Moçambique. A escolha deste programa prende-se pelo fato de este ser feito em línguas nacionais e escutado em todas as províncias de Moçambique. No entanto é de salientar que os mesmos métodos foram usados na recolha de dados em São Tomé e Príncipe, onde foi possível localizar, identificar e gravar depoimentos dos deportados que se encontram neste arquipélago desde os anos Cinquenta graças à ajuda de emissoras radiofónicas locais. 
Uma vez localizadas, as fontes diretas e alguns familiares delas foram entrevistadas em São Tomé e Príncipe. Tais entrevistas foram de tipo qualitativo e, aberto, procurando saber das razões da deportação, do dia-a-dia dos deportados ao longo do período laboral, e finalmente da sua condição atual e de possíveis contatos que o Estado moçambicano teve com eles depois da independência em 1975. Com os retornados, se quis saber também como é que foi possível o retorno a Moçambique, e que tipo de laços mantém com possíveis familiares que tenham ficado em São Tomé e Príncipe. Os entrevistados, portanto, foram induzidos a pensar e expressar de forma livre e descontraída sobre o assunto (DUARTE, 2015), sendo eles próprios o sujeito da pesquisa, tendo em conta os traços subjetivos do ator e suas particularidades. Este método de pesquisa analisa em profundidade dados de difícil mensuração de um determinado grupo de indivíduos em relação a um problema específico. Entre eles estão sentimentos, sensações e motivações que podem aplicar determinados comportamentos, apreendidos com o foco no significado que adquirem para os indivíduos.

Cada entrevistado expressou suas particularidades e subjetividades. No caso dos deportados que se encontram em São Tomé, entrevistá-los sobre um assunto em que eles são as vítimas de uma história "global" deu, como um dos resultados metodologicamente e epistemologicamente mais relevantes, a inversão de papéis com o entrevistador. A dada altura os entrevistados queriam saber do entrevistador se era possível localizar os seus familiares e Ihes dizer se ainda estariam vivos, quem era 0 presidente de Moçambique e muitas outras questões que ao longo das entrevistas iam surgindo. Questões encaradas com naturalidade, por se tratar de indivíduos que, à distância geográfica que os separa da sua pátria, se associa a falta de informação que os coloca distantes das suas culturas de origem.

Neste sentido, tais entrevistas foram realizadas mediante uma abordagem narrativa, em que a colaboração entre entrevistado e entrevistador é fundamental, e "the story emerges from the interaction exchange and dialogue between interviewer and participants"” (MUYLAERT, SARUBBI, GALLO, ROLIM NETO \& REIS, 2014, p. 85).

\footnotetext{
2 “A história emerge da interação, troca e diálogo entre o entrevistador e os participantes".
} 
Uma das provas da eficácia desta abordagem deu-se quando um deportado, meia hora antes da entrevista, decidiu criar personagens e montar cenário para contar a sua própria história, esgotando o pouco recurso que dispúnhamos para gravação de depoimentos dos outros entrevistados. Em São Tomé e Príncipe foi possível entrevistar doze deportados e três descendentes, como fontes diretas.

Entretanto, em consideração da complexidade do assunto, achou-se necessário ouvir a opinião de fontes indiretas relacionadas com o caso (informantes-chave). Tais informantes-chave foram a diretora do asilo onde se encontra a maior parte dos deportados, Elsa Viana, Maria de Conceição que em troca de serviço, dá ao deportado na sua responsabilidade alojamento, alimentação e vestuário. Entrevistou-se também o escritor e pesquisador social Albertino Bragança, um dos poucos a ter acompanhado a história desses deportados, do lado de São Tomé e Príncipe.

Ainda na tentativa de compreender as diferentes facetas desta história, foram entrevistados, do lado moçambicano, três fontes diretas (dois regressados e um descendente), além de inúmeros informantes-chave, tais como: o antigo Presidente da República, Joaquim Chissano, que tem acompanhado o caso quer como Ministro dos Negócios Estrangeiros até 1986 e, depois, como Chefe de Estado, de 1986 até 2004; o então Presidente da Comissão Nacional dos Direitos Humanos, Custódio Duma, o sociólogo Eugénio Bras, o arquivista Bartolomeu Rungo, o Presidente da comunidade Muçulmana da Ilha de Moçambique, Hafiz Habdurrazaque, e o antigo diretor do Jornal Notícias, Álvaro Macaringue. Todas estas testemunhas trouxeram pontos de vista e conhecimentos diferentes acerca dos deportados, ajudando na compreensão do fenômeno. As entrevistas foram gravadas em formato audiovisual com recurso a uma câmara de filmar. Finalmente, foi feita uma entrevista também em Cabo Verde com o antigo Diretor Geral das Comunidades na diáspora, Francisco Carvalho, para ouvir o posicionamento do Estado cabo-verdiano diante do desterro dos seus cidadãos para São Tomé e Príncipe.

Se as entrevistas constituíram o método principal desta pesquisa, outros, ainda de tipo qualitativo, serviram como complemento à principal ferramenta acima mencionada: foram analisados conteúdos jornalísticos publicados após a independência sobre os 
deportados durante seis meses de visitas ao Arquivo Histórico de Moçambique, Biblioteca Nacional, Jornal Notícias, Rádio Moçambique e Televisão de Moçambique. A literatura especializada trouxe as ferramentas essenciais para enquadrar a história da deportação aqui analisada no seio de uma visão mais geral que encontra na memória coletiva esquecida e nos direitos humanos violados as suas referências fundamentais.

\section{Enquadramento teórico: o desterro entre memória negada e violação dos direitos humanos}

Quando se faz referência ao desterro, no contexto histórico aqui abordado, é preciso tomar em consideração duas dimensões fundamentais: por um lado, uma material, física, que diz respeito ao desenraizamento e sucessiva deportação de indivíduos - neste caso oriundos em prevalência de Moçambique - para outra localidade (São Tomé e Príncipe), de forma violenta e coerciva (salvo os formalismos legais do “contrato"); por outro, uma espiritual e imaterial, que mexe com o direito à memória e às identidades coletivas, segundo um processo que pode ser definido de "desterro da memória", consoante uma feliz expressão usada a propósito de um romance do escritor moçambicano Mia Couto, o último voo do flamingo (OLIVEIRA \& GUIMARÃES TELLES, 2015).

Nestas duas dimensões do desterro é possível encontrar a síntese da dupla violação de direitos humanos fundamentais a que os deportados foram submetidos. Acima de tudo, do ponto de vista individual, cada deportado ou serviçal viu a sua vida "negada", de forma muito próxima a quanto se passou com a escravatura, pelo menos até 1910, aquando da instauração da república; depois dessa data "um regime contratual e o trabalho forçado vigoraram alternadamente ou coexistiram nas roças" (NASCIMENTO, 2004a, p. 189), não trazendo grandes melhoramentos à condição concreta dos serviçais (CONCEIÇÃO NETO, 2017), mais uma vez comparável com a dos escravos (COOPER, 2005).

Porém, do ponto de vista coletivo e imaterial, os acontecimentos "vividos por tabela" (POLLACK, 1992) revelam outras violações, não menos graves do que as anteriores, e que dizem respeito ao esquecimento das vicissitudes de um grupo 
consistente de pessoas, excluído da história oficial. Como alguém tem realçado, os vários estatutos dos indígenas aprovados desde 1899, culminados com o DL 39.666 de 1954, contribuíram a fazer com que "o desaparecimento" fosse "o destino que a História reservava aos indígenas", ou por via da sua "civilização" ou mediante a eliminação física pelas tropas ocidentais (NOGUEIRA, 2009, p. 18). A adesão de Portugal a todos os acordos internacionais contra o trabalho forçado, inclusivamente a Convenção da Liga das Nações de 1926 e a Convenção n. 29 da Organização Internacional do Trabalho de 1930 não passaram de meros atos formais, tão que uma série de denúncias foram feitas por parte de vários observadores estrangeiros, sobretudo ingleses e americanos, obrigando Portugal a defender-se diante da Comissão Temporária da Escravatura da Liga das Nações em 1925, em seguida à apresentação do relatório-Ross (GONÇALVES, 2017).

O "desaparecimento" da memória dos desterrados foi avalado mesmo por analistas muito conceituados da história de São Tomé e Príncipe, segundo os quais “à data da independência, apenas se quedavam pelo arquipélago os que, em dado momento, terão prescindido do regresso" (NASCIMENTO, 2004a, p. 199). Circunstância que a pesquisa aqui apresentada procura desmentir, mediante as evidências encontradas no terreno.

O processo de solidificação da história, em que "os fatos sociais se tornam coisas" (POLLACK, 1989, p. 4), estratificando-se em memória coletiva reconhecida e oficializada é alheio aos acontecimentos "vividos por tabela" dos moçambicanos desterrados de que este artigo trata. Com efeito, cada um deles guarda recordações, experiências, convivências, abusos e violações de forma individual, mas nunca tais estórias passaram a ter uma dignidade coletiva, ficando numa condição que foi chamada de "latência colonial” (MENEZES, 2010): não existem monumentos, património arquitetónico, paisagens (a não ser, genericamente, as “roças”), assim como datas, tradições, hábitos que compõem o mosaico comum da história destes deportados (HALBWACHS, 1990). O que confirma a enorme clivagem entre história e memória (SOUZA CORREIA, 2011), entre mundo ocidental e mundo do "outro", que a crítica pós-colonial eficazmente tem representado (SOUSA SANTOS, 2007; MENEZES, 2010) e a que este artigo procura dar uma primeira resposta. 
Se é evidente que ninguém poderá devolver as vidas quebradas aos deportados, o que é possível fazer é inserir tais existências no seio de uma memória coletiva reconhecida publicamente, e finalmente numa história oficial do colonialismo e do póscolonialismo português em África.

\section{O desterro: um breve historial}

A história dos moçambicanos em São Tomé e Príncipe é a história da escravatura e do trabalho forçado a que o povo moçambicano fora submetido no passado colonial (SÁ, 1974, p. 7).

Quando em 1470, os Portugueses chegaram a São Tomé, a ilha era desabitada. O seu povoamento começou oficialmente em 1493, por parte de colonos brancos portugueses e de escravos africanos. Com o desenvolvimento do tráfico de escravos especialmente de Angola, devido a sua situação geográfica privilegiada, São Tomé se transformou no centro de armazenamento e carregamentos de seres humanos que eram depois deportados para as Antília e para o Brasil (SÁ, 1974, p. 36), constituindo assim uma segunda base para este comércio, depois da primeira feitoria de Arguim (Mauritânia), em 1448. Um primeiro momento de prosperidade económica foi alcançado nos séculos XV e $\mathrm{XVI}$, com o processo de povoamento e crioulização (SEIBERT, 2015).

As capturas de escravos nas costas africanas eram feitas pelos negreiros, que depois os vendiam para os mercados mundiais. $O$ arquipélago funcionava como principal interposto, onde as grandes companhias esclavagistas estabeleceram a base para os seus negócios. O comércio de escravos constituiu a partir do século XVI a principal fonte de receitas para Portugal naquela ilha, juntamente com a cultura da cana-de-açúcar, mais tarde substituída pelo café e, finalmente, pelo cacau (SEIBERT, 2015). A mão-de-obra escrava provinha essencialmente de Cabo-Verde, Angola, Moçambique e especialmente do Gabão, país mais próximo à ilha, do Congo e do Benim (HODGES; NEWITT, 1988). As propriedades da alta finança de Lisboa importavam anualmente 10.000 trabalhadores das restantes colónias portuguesas de África, e obrigavam-nos a uma existência de escravos, embora assumindo um semblante formal diferente nas épocas mais recentes (SÁ, 1974). 
Depois do século XVI São Tomé e Príncipe perdeu a sua importância económica e foi quase que abandonado, até o século XIX, altura em que se deu a segunda colonização do arquipélago (SEIBERT, 2015). Esta colonização esteve diretamente ligada às condições da economia portuguesa ao longo da segunda metade do século XIX, altura em que este país “foi forçado a especializar-se na produção de produtos primários, uma boa parte da qual era exportada para um mercado largamente dominante - a Inglaterra", que, por seu turno, mandava para Lisboa produtos manufaturados, contribuindo assim significativamente a retardar a evolução industrial lusitana (REIS, 1984: 9). Desta forma, Portugal tornou-se por um lado periférico no interior da economia europeia, por outro largamente dependente da Inglaterra, já não podendo mais contar com as enormes riquezas de Brasil, independente desde 1822 (CABRAL, 1976). Assim, Portugal - inserido de forma subsidiária numa economia internacional cada vez mais globalizada - teve de perpetuar o trabalho forçado, embora saindo formalmente da escravatura que no entretanto a Inglaterra e os outros países ocidentais começaram a combater duramente. Em suma, o contraditório preço da inserção de Portugal no capitalismo globalizado moderno - contrário à escravatura - foi de encontrar estratagemas jurídicos para perpetuar a mesma escravatura, única forma de organização de trabalho para responder à demanda de matéria-prima daquele mesmo capitalismo (CAHEN, 2015).

Os níveis de dependência, quer económica quer política de Portugal para com a Inglaterra já eram patentes desde os primeiros anos do século XIX. Dois tratados de 1810, assinados entre a coroa portuguesa (na altura residente no Rio de Janeiro, sob proteção inglesa) e a britânica - de Comércio e Navegação e de Aliança e Amizade - tinham decretado a primazia económica de Londres sobre Lisboa, inclusivamente a respeito do mercado brasileiro (RAMOS, 1988), elegendo o Reino Unido como nação mais favorecidas para Portugal (PIMENTEL, 2013). Além dos aspetos comerciais, Portugal aceitava de futuramente abolir também a escravatura (que a Inglaterra tinha declarado ilegal desde 1807), limitando-a de imediato (no Brasil) à Costa da Mina e aos países africanos sob controlo lusitano (ALEXANDRE, 1991). Em 1814, nas vésperas do Congresso de Viena, Portugal assinou dois tratados com a Inglaterra acerca da abolição da escravatura, mas foi em 1815, durante o Congresso de Viena, que os dois Estados assinaram um tratado 
bilateral em que o tráfico esclavagista foi declarado ilegal ao norte do Equador, e só dois anos mais tarde a marinha de guerra inglesa começou a ter a prerrogativa de visitar e fiscalizar os navios portugueses suspeitos de transportar escravos. Entretanto, Portugal estava autorizado a fazer comércio de escravos a Sul do Equador, nomeadamente a levar escravos para Brasil das suas colónias africanas (PIMENTEL, 2013). Finalmente, a Inglaterra conseguiu uma grande vitória moral, ao fazer com que (Anexo XV da Declaração Final do Congresso de Viena) os oitos países do Congresso condenassem a escravatura como contrária aos princípios fundamentais da humanidade e à moral (IDEM).

Se Portugal tinha a função de fornecedor de matérias-primas agrícolas no mercado mundial, as altas salariais e a organização sindical dos trabalhadores na madre-pátria, formalizada - para o ramo da agricultura - com decreto de 9 de Maio de 1891 mas já existente em várias partes do país (BERNARDO, 2002), contribuíram a fazer com que o foco das atenções do capitalismo português se concentrasse no além-mar, nomeadamente na colónia potencialmente mais produtiva, São Tomé e Príncipe, procurando "taxas de lucro tornadas impossíveis" em território lusitano (CABRAL, 1976, p. 121). Entretanto, o que estava a faltar em S. Tomé era a mão-de-obra, abundante nas outras colónias africanas portuguesas, que desempenharam assim o importante papel de fornecedoras de trabalhadores a custo muito baixo ou até completamente gratuito.

A dificuldade estava toda nesta questão: como usar uma mão-de-obra praticamente esclavagista, contornando os impedimentos formais à prorrogação deste instituto? Nos anos que se seguiram ao Congresso de Viena, a Inglaterra continuou a ser o paladino internacional da abolição, o que se traduziu numa crescente pressão a Portugal. O s "imediatistas" ingleses acabaram conseguindo seus objetivos já em 1838, cortando o relativamente longo período de "formação" reservado aos antigos escravos antes de se tornarem definitivamente livres, previsto no Bill de 1833 de Lord Palmerston. Em paralelo, em Portugal a questão foi muito mais complexa, carregando-se de significados políticos e nacionalistas que iam muito além da simples conveniência económica. Acima de tudo, a opinião pública local não tinha um posicionamento abolicionista como na Inglaterra, com poucas exceções, por exemplo Sá da Bandeira; 
entretanto, a importância económica da escravatura era tão relevante que ela podia ser até classificada como "um estado socialmente lamentável”, mas que devia "prosseguir, visto ser fundamental para a sobrevivência das colónias" (MARQUES, 2001, p. 215). Não foi por acaso que o projeto de lei apresentado pelo Ministro da Marinha, Sá da Bandeira, foi rejeitado sem grandes incertezas (IDEM), e que o próprio decreto aprovado a 10 de Dezembro de 1836 deixava muitas ambiguidades no que toca à abolição da escravatura em território português (IDEM). No mesmo ano, o recém-chegado governador português de Angola, Domingos de Oliveira e Daun, encontrou cerca de 30 navios entre os portos de Luanda e de Benguela, prontos para se dirigir a Brasil, cheios de escravos (ALEXANDRE, 1991).

\footnotetext{
Apesar das resistências quer de cunho político quer de tipo económico, a 3 de Junho de 1842 Portugal assinou um tratado específico com a Inglaterra para a abolição da escravatura, registando, porém, uma "ampla resistência da opinião pública portuguesa", inclusivamente por interpretar este acordo como ingerência estrangeira à soberania nacional (ZAMPARONI, 2004, p. 300).
}

Foi apenas em 1875 que Portugal assumiu - pelo menos formalmente - o fim da escravatura. Entretanto, um dos intelectuais portugueses mais influentes dos finais do século XIX, Oliveira Martins, ainda em 1920, escrevia que era necessário encontrar "um meio de tornar forçado o trabalho do negro, sem cair no velho tipo condenado da escravidão" (OLIVEIRA MARTINS, 1920, p. 233).

Embora de forma dificultosa e constantemente sob o olho vigiador da Inglaterra, Portugal criou um pano de fundo legal que conseguiu contornar o instituto da escravatura, garantindo-se uma ampla liberdade nas suas colónias africanas, mediante mecanismos jurídicos e prático-disciplinares novos e eficazes para perseguir seus objetivos económicos (ZAMPARONI, 2004). Por exemplo, em 1904 foi criada a Curadoria dos Negócios Indígena, transformada em 1907 em Secretária, com poderes judiciários bastantes para deportar os indígenas "perigosos" para outros distritos. No caso de Moçambique, isso significou concentrar estes indivíduos aprisionados na llha de Moçambique (ZAMPARONI, 2004). Em 1916 foi introduzida a pena de trabalho correcional, abolida apenas em 1962, paralelamente à abolição do estatuto do indigenato. Como conclui Zamparoni, “os vários regulamentos do trabalho indígena eram detalhados 
quanto às obrigações dos indígenas, mas extremamente imprecisos e dúbios quanto aos seus direitos" (ZAMPARONI, 2004, p. 307).

Entre as tentativas feitas para garantir um fluxo constante de mão-de-obra em São Tomé e Príncipe é preciso recordar aqui o caso dos coolies. A este propósito, o Banco Nacional Ultramarino, interessado ao desenvolvimento económico de São Tomé e Príncipe, encarregou um mercante de vinhos da Madeira, Carlos Blandly, para contratar fora da colónia o pessoal que devia trabalhar nas plantações de cacau, nomeadamente na Libéria, e sobretudo na Angola, em Moçambique e em Cabo-Verde. Até 1876 mais de 3000 trabalhadores chegaram a São Tomé (MIGUEL, 2011). O cacau, originário da América Centro-Meridional, foi implantado, ao longo do século XIX, em África. A primeira plantação africana de cacau foi instalada em São Tomé e Príncipe por volta de 1855.

A outra estratégia adotada pelo Estado português veio, por assim dizer, do outro lado, ou seja, da madre-pátria. Segundo o relato de um médico português daquela altura, Manuel Ferreira Ribeiro, os indígenas eram desprovidos de qualquer propensão para o trabalho, pelo que era necessário procurar outros indivíduos mais aptos para o efeito (JOBBITT, 2016). Por outra, o mesmo médico defendia que os europeus não reuniam as condições físicas para trabalhar nas plantações, uma vez que, quando isso acontecia, eles ficavam doentes, até a falência. O problema devia-se resolver, segundo o médico, mediante uma força laboral ainda europeia, mas já em parte habituada a trabalhos pesados em condições ambientais desfavoráveis: os “degredados”. Os degredados eram portugueses que - devido a crimes comuns, políticos ou até religiosos - eram condenados à pena do degredo. Tal pena conheceu, durante cerca de sete séculos de aplicação, várias formas de efetivação, mas no século XIX ela se consubstanciou na expulsão, ou seja, numa migração forçada dos condenados para o povoamento das colónias e o trabalho nas grandes plantações africanas assim como brasileiras (TOMA, 2006).

Quarenta anos mais tarde uma crise braçal induziu alguns dos roceiros a importar a necessária mão-de-obra da Ásia, nomeadamente da Índia e da China (os ditos coolies), via Macau (NASCIMENTO, 2004b). Uma experiência, porém, negativa, devido à alta taxa de mortalidade, quer de chineses, quer de indianos, nas roças de São Tomé. Foi assim que 
se chegou à conclusão de que a importação de trabalhadores africanos continuava como sendo a opção preferível, sobretudo em épocas particularmente propícias para a comercialização de cacau e café, por exemplo logo depois do fim da segunda guerra mundial.

Foi nestas circunstâncias que as autoridades de Moçambique começaram a definir e a fabricar indesejáveis para depois deporta-los ou desterra-los para São Tomé e Príncipe, para fazer face a resistência dos nativos ao trabalho forçado e à paralela necessidade de procurar uma mão-de-obra ao mesmo tempo barata e resistente, contornando a proibição do uso de escravos.

A história da migração forçada dos moçambicanos para São Tomé e Príncipe ao longo do século XX se distingue em duas fases - 1908 a 1921 e 1947 a 1961 - mediadas por um interregno.

No início do século, a partir de 1903, deportações de serviçais para trabalhar nas roças de São Tomé tinham envolvido cabo-verdianos, ao passo que foi apenas em 1908 que começaram as deportações de moçambicanos (NASCIMENTO, 2004a). Este novo fluxo de trabalhadores para São Tomé encontra a sua explicação na necessidade de incrementar a produção de cacau para exportação nos mercados mundiais, devido a uma conjuntura internacional favorável, até aproximadamente o início dos anos 1920.

As condições de trabalho dos serviçais pioraram repentinamente: se, ainda nos finais do século XIX havia momentos de lazer nas roças, a partir do século XX a deterioração é de tal entidade que se registaram "elevadas taxas de mortalidade de serviçais" (NASCIMENTO, 2004a, p. 191). Apesar de os deportados moçambicanos gozarem um estatuto relativamente privilegiado, tendo direito ao retorno (clausula imposta pelo governador de Lourenço Marques, Freira de Andrade), suas condições de trabalho e de vida não diferiam das dos demais.

No interregno que se registou entre os anos 1920 e 1940 o fluxo de deportados das outras colónias portuguesas para São Tomé reduziu, devido à situação internacional de crise nos principais mercados de importação (Estados Unidos e Europa) e depois da segunda guerra mundial, com uma queda muito significativa da exportação do cacau 
produzido em São Tomé. De 1921 a 1926 tal exportação passou de 26.283 toneladas por ano a 12.470, tocando o pico negativo em 1940, com 6.972 toneladas (SEIBERT, 2002).

Em paralelo, o declínio das empresas portuguesas em São Tomé foi também considerável: juntamente com a deterioração das condições de trabalho dos serviçais, as relações de poder entre roçeiros e autoridades públicas virou em favor dos primeiros, que exigiam cada vez mais trabalhadores a atuarem em condições comparáveis com a escravidão, tão de induzir os governadores das outras colónias a desenvolver formas de resistências na disponibilização de tais trabalhadores (NASCIMENTO, 2004a).

Foi a partir do Estado Novo (1933) que tais relações voltam a encontram um equilíbrio maior; esta circunstância, associada ao fim da segunda guerra mundial em 1945, fez com que o mercado do cacau ganhasse um novo folego. Assim, as exportações sãotomenses desta matéria-prima para os mercados internacionais voltaram a registar incrementos significativos, que precisaram de uma política pública específica que garantisse um fluxo constante e suficiente de serviçais. Entre 1954 e 1957 as exportações de cacau produzido em São Tomé aumentaram de 6.972 para 12.470 toneladas, fato que justificou a nova vaga de deportações de trabalhadores da colónia moçambicana (SEIBERT, 2002).

Primeiros sinais desta nova vaga de deportações se deram já em 1948, quando um número não especificado de moçambicanos foi apreendido na cidade de Lourenço Marques e deportado para São Tomé e Príncipe em condições desumanas (NASCIMENTO, 2005). Três anos mais tarde, em 1951, a produção de “indesejáveis" na colónia moçambicana já era um dado adquirido, representando um meio legalmente perfeito para contornar as restrições em matéria de trabalho forçado que a comunidade internacional não podia mais aceitar de Portugal, sobretudo com a aprovação da Declaração Universal dos Direitos Humanos de 1948 e, poucos anos mais tarde, com a Convenção sobre o Trabalho Forçado da Organização Internacional do Trabalho de 1957. Com uma demanda internacional em crescimento (as exportações do cacau são-tomense passaram de 6.972 para 12.470 toneladas entre 1954 e 1957), foram poucas as autoridades coloniais que recusaram-se em fornecer homens para o trabalho nas plantações de São Tomé ao longo desta segunda fase do desterro (NASCIMENTO, 2005). 
O processo de desterro e de importação de trabalhadores de Moçambique, Angola e em parte Cabo Verde para o arquipélago atlântico desacelerou nos finais dos anos Sessenta e início dos anos Setenta, quando a economia mundial e europeia registou uma estagnação, que envolveu também São Tomé e às suas culturas de cacau e café (VALÉRIO \& TJIPILICA, 2006).

O desterro era, em boa verdade, uma escravatura disfarçada mediante improváveis cláusulas contratuais, que só serviam para salvar as aparências, principalmente diante (mais uma vez) da fiscalização britânica. Ainda nos meados dos anos Cinquenta do século passado, um zelante administrador colonial em São Tomé, Francisco Mantero, realçava como a opção de os moçambicanos emigrarem à procura de melhores condições de emprego tivesse sido livre e até conveniente, consideradas as condições oferecidas pelo Estado português. E como, portanto, os britânicos não deviam apontar para esta prática como sendo esclavagista (MANTERO, 1954).

Em 1961, ano aqui considerado como o fim da segunda fase do desterro, com a abolição legal das diferenças de estatuto entre "indígenas e assimilados 3 e as reformas introduzidas pelo Ministro de Ultramar, Adriano Moreira, o curador geral só passou a autorizar contratos para o arquipélago em casos absolutamente justificados. A 27 de Abril de 1962, o decreto-lei $n^{\circ} 44309$ aprovou o código de trabalho rural, interditando o trabalho obrigatório e o recrutamento forçado e, pela primeira vez São Tomé e Príncipe não importou nenhum trabalhador moçambicano e nem de outras origens. As repatriações prosseguiram até os primeiros dias de 1967, diminuindo o contingente de moçambicanos no arquipélago" (NASCIMENTO, 2005), mas sem completar um tal processo, como demonstrado pelos antigos serviçais encontrados em asilos de idosos em São Tomé.

Se, por um lado, o capítulo da deportação de moçambicanos chegava ao fim, por outro iniciava-se o capítulo dos que ficaram no arquipélago entregues a sua própria sorte à espera do repatriamento, no esquecimento geral quer das autoridades públicas, quer da historiografia oficial.

\footnotetext{
35egundo o escritor são-tomense, Albertino Bragança, indígenas é mesmo que dizer nativo. Já a assimilação foi uma política implementada por Portugal e a França, na tentativa de destruir os hábitos culturais do povo africano, incutindo nos nativos que colaboravam com sistema, hábitos e costumes europeus.
} 


\section{As vozes dos "desterrados" moçambicanos em são Tomé e Príncipe}

Neste ponto, além do pouco material disponível, serão usadas as entrevistas feitas quer em Moçambique quer em São Tomé e Príncipe e Cabo Verde para determinar os seguintes aspetos, relativos à segunda fase do desterro (1947-1961):

1. Como é que acontecia o processo de recrutamento da mão-de-obra a ser exportada para São Tomé?

2. Que tipo de contrato era celebrado entre as duas partes?

3. Que tipo de existência era levada a cabo por parte dos deportados nas roças de São Tomé e qual a situação atual dos deportados ainda em vida?

4. Que tipo de iniciativa tem assumido o Estado moçambicano para aliviar a existência dos seus cidadãos e dos descendentes deportados que ainda vivem em São Tomé?

1. O processo de recrutamento. Muito fora do posicionamento oficial português, recordado sucintamente mediante o livro de Mantero, o desterro foi uma operação levada a cabo para garantir a produção de cacau e café na colónia mais produtiva do decadente império lusitano ao longo da segunda metade do século XX. Devido aos problemas de recrutamento de mão-de-obra fora de um contexto esclavagista, a forma aceitável aos olhos da cada vez mais vigiante comunidade internacional foi mediante a “repressão desproporcionada de pequenos delitos" (NASCIMENTO, 2011, p. 57). Este procedimento permitia que tais casos se resolvessem via administrativa e não judiciária, como muito dos entrevistados confirmaram, deixando um maior espaço de manobra ao Estado colonial. Qualquer trabalhador que se recusasse ao trabalho forçado, que não pagasse o imposto de palhota, que abdicasse da cultura do algodão em certas regiões do país, ou que de alguma forma manifestasse o mínimo de resistência ao colono, era imediatamente deportado para São Tomé. O mesmo resultado se dava com acusações de tipo sexual (por exemplo quando a patroa mascarava com a violação casos de relações sexuais consencientes com negros, para salvar a sua dignidade e o seu bom nome), assim como de vadiagem (quando um moçambicano era encontrado na rua sem meta aparente e era preso e depois deportado pelas autoridades coloniais). Assim, a acentuação de 
punições por fatos minutos ou até inexistentes se transformou no maio mais eficaz para garantir o fluxo de deportados para São Tomé.

Adriano de Jesus é um deportado regressado, cuja história é emblemática acerca de como o governo colonial português Ihe deportou para São Tomé. ${ }^{4}$ Conta ele que os portugueses consideravam aos moçambicanos como sendo bandidos, gente que andava de noite a perturbar a ordem pública. Ele foi apanhado de noite, enquanto simplesmente andava na rua, foi algemado e encarcerado. Lhe meteram no primeiro barco, e ficou 12 anos em São Tomé. Muito parecido é o conto de Fastel Muianga, conhecido como Fabião, que ainda se encontra em São Tomé e Príncipe..$^{5}$ Originário de Gaza, Fabião foi a Lourenço Marques à procura de melhores condições. Aqui, no bairro do Chamanculo, Fabião conta que havia uma igreja evangélica onde ele ia. Entretanto, por volta das 18.00 horas, um polícia português lhe manda parar e lhe encarcera numa prisão. "Ficámos ali - recorda Fabião - por três meses. Quando chegou o barco, fomos". Andar de noite representava um potencial, suposto risco, segundo as autoridades coloniais, portanto os que eram capturados nestas circunstâncias eram considerados de indivíduos perigosos, vadios, por isso eram presos e, à primeira oportunidade, embarcados para São Tomé. Havia, entretanto, outras circunstâncias que serviam para que as autoridades portuguesas considerassem de perigoso um indivíduo, e o enviassem para as roças. Mário Mbebela, conhecido por Walekaya, conta com pormenores a sua história, confirmando como a agravação de pequenos crimes ou até de situações irrelevantes do ponto de vista judiciário serviram para produzir serviçais para trabalhar nas roças de São Tomé.: “ "Uma senhora branca faltou-me de respeito, queria-me esbofetear". Mas, sendo ele homem, não podia aceitar uma tal humilhação. A senhora respondeu que "Você é homem, mas você é negro", e recorda que ela Ihe bateu. "Mulher - afirma Walekaya - não pode bater o homem", pior se isso acontece publicamente, diante das outras pessoas. Foi assim que o rebelde Walekaya foi mandado para São Tomé, onde veio a falecer ano passado, depois de tantas tentativas por parte de alguns moçambicanos que se comoveram com a sua história para lhe ajudar a voltar às suas origens. Segundo o antigo Presidente da

\footnotetext{
${ }^{4}$ Adriano de Jesus foi entrevistado em Maputo, nos locais do Bairro da Mafalala, no dia 10/02/2013

${ }^{5}$ Fastel Muianga foi entrevistado em São Tomé e Príncipe, nos locais de Riboque Santana, no dia 23/12/2013

${ }^{6}$ Mário Mbebela foi entrevistado em São Tomé e Príncipe, nos locais do Monte Macaco, no dia 30/12/ 2013.
} 
República de Moçambique, Joaquim Chissano, que foi uma testemunha indireta destas deportações, a razão principal do desterro era justamente o suposto desrespeito que pudesse surgir contra o patrão português, ou contra a patroa. ${ }^{7}$ Aliás, Chissano recorda vários episódios em que a patroa denunciava o serviçal, queixando-se de que este lhe teria aproximado ou até violado, exigindo uma punição exemplar. Segundo Chissano, o que acontecia, na maioria dos casos, era que a patroa queria manter relações sexuais com um serviçal, mas depois se arrependia ou temia o escândalo, pelo que a única forma para limpar a sua imagem era de denunciar o caso. E o fim da história era o desterro do serviçal para São Tomé.

Finalmente, uma última tipologia de deportação era feita mediante a alteração do contrato que o serviçal tinha assinado com o patrão. Como conta Bartolomeu Rungo, arquivista moçambicano, ${ }^{8}$ havia, já naquela altura, um considerável fluxo de migração do campo para Lourenço Marques. O jovem assinava o contrato como serviçal e iniciava a trabalhar. Geralmente a duração dos contratos era de 18 meses, mas o trabalhador só recebia no fim do contrato. Por volta do $16^{\circ}$ mês, realça o dr. Rungo, o patrão arranjava uma desculpa qualquer para não pagar o serviçal, que passava portanto por um rápido processo e geralmente era enviado para São Tomé com o objetivo de cumprir a sua pena. Os dois centros principais donde os deportados saíam eram llha de Moçambique e Mussuril. Como recorda Hafiz Abdurrazaque, Presidente da Comunidade Muçulmana na Ilha de Moçambique, primeira capital portuguesa da colónia moçambicana, os processos para os ditos "perigosos" eram celebrados na Ilha, onde ainda havia o Tribunal Supremo. Daqui embarcavam para São Tomé ou eram levados até Mussuril, onde havia uma Feitoria e donde também seguiam para São Tomé.

2. Os aspetos contratuais. Segundo o citado livro de Mantero, os contratos eram completamente livres, prevendo inclusive descontos que deviam servir para o regresso do trabalhador no fim do período de vigência contratual. Inicialmente, os agricultores da colónia portuguesa de São Tomé e Príncipe eram obrigados, no âmbito do decreto de 31

\footnotetext{
7 Joaquim Alberto Chissano foi entrevistado em Maputo, nos locais da Fundação Joaquim Chissano, no dia 25/09/2014

${ }^{8}$ Bartolomeu Rungo foi entrevistado em Maputo, nos locais do Arquivo Histórico do Campus Universitário, no dia 17/09/2014
} 
de Dezembro de 1908, mais tarde substituído pelo decreto de 17 de Julho de 1909, a contratar os serviçais procedentes de outras províncias portuguesas, garantindo-lhes todas as regalias para sua subsistência incluindo a sua passagem de volta a sua terra de origem e a entrega das poupanças no fim do contrato. O cumprimento destas obrigações era fiscalizado pelas autoridades, pelas juntas de emigração e pelo Curador dos indígenas; os indígenas, consoante a versão oficial, tinham o direito e uma ampla liberdade de se queixar e de pedir providência ao Curador, contra a falta de cumprimento das obrigações estipuladas nos contratos, ou contra quaisquer abusos que os patrões tivessem praticado em prejuízo das pessoas e dos interesses dos indígenas (MANTERO, 1954, p. 95). Depositado no fundo da Direção dos serviços dos negócios indígenas (Conf. Caixa 950), um dos contratos de prestação de serviços para São Tomé e Príncipe assim rezava: “Celebrado na subintendência de Moçambique sob os números adiante indicados. Nos termos dos Decretos $N^{0} 11.491$ e 11. 492, transcritos no Boletim oficial " $N^{0} 19$, I série, de 8 de Maio de 1929, e mais legislação em vigor, António Rosa Cabral, em nome da sociedade de Emigração para São Tomé e Príncipe, contrata para a prestação de serviços os indígenas a seguir indicados, que declaram perante mim desejarem contratar-se livremente e sem qualquer imposição, para irem servir por dois anos nas ilhas de São Tomé e Príncipe, com direito ao salário e todas as regalias consignadas nos ditos Decretos e demais legislação em vigor. O Patrão obriga-se ao cumprimento do presente contrato e, terminado este, a repatriar o trabalhador para Moçambique, onde foi recrutado, e às demais disposições legais em vigor, em especial a uma compensação quando de desastre no trabalho, nos termos da base 19 do "modus vivendi" (Decreto $N^{\circ} 11.491$ ). Lavrado em Moçambique, 11 de Julho de 1928, assinado por António Rosa Cabral, Agencia da Sociedade". Na verdade, a realidade nas roças em São Tomé e Príncipe era bem diferente, como relatam os entrevistados e como a literatura especializada tem demonstrado (SEIBERT, 2002; NASCIMENTO, 2011). Fastel Muianga (Fabião), conta que depois de ter sido apreendido e encarcerado durante três meses, só ficou a saber qual seria o seu destino, dias antes de ser transportado para a embarcação. Afirma que assim como os outros que estavam na mesma situação, não teve a oportunidade de ser ouvido e muito menos informado sobre o tipo de trabalho que o esperava, as condições e quando 
voltaria para Moçambique. "Não nos despedimos da nossa família, saímos da prisão amarados por cordas, dois a dois. Durante a viagem, tivemos boa alimentação e cama para dormir. Mas quando chegamos cá, no primeiro dia, serviram-nos uma espécie de arroz confecionado com óleo de palma e sal que parecia uma papa de farinha de milho amarelo, não conseguimos comer. Neste mesmo dia, deram-nos pão e água e colocaramnos para dormir no secador de cacau sem condições. Eu tinha 17 anos, mas havia famílias no grupo, mulheres com crianças, mas dormimos todos no mesmo lugar. No dia seguinte, fomos apresentados na feitoria e lá ficamos a saber que iriamos cumprir um contrato de trabalho e os anos variavam consoante a idade. Nós não escolhíamos para onde ir, até porque não conhecíamos o local onde estávamos, éramos escolhidos pelos patrões de cada roça existente naquela altura e, não podíamos falar nada, éramos tratados como escravos. Lembro-me que depois de ter cumprido os anos de contrato que disseram que eu deveria cumprir, fui-me apresentar à feitoria e disseram-me que faltavam mais três anos que eu pedi para trabalhar. Eu não havia pedido nada e não podia falar nada", contou Fabião, visivelmente alterado". 9 Para os casais que tivessem filhos com idade superior a 14 anos, a administração decidia repatriar os pais e, os filhos ficavam para os substituir, como foi o caso de João Afonso Alfane ${ }^{10}$, um dos muitos moçambicanos acolhidos pela Santa Casa da Misericórdia de São Tomé e Príncipe por não ter parentes no Arquipélago. "Meus pais voltaram para Loureço Marques e nunca mais ouvi falar deles. Fiquei porque o branco não aceitou que me levassem. Eu vim para cá com eles e fazia pequenos trabalhos na roça." Este caso deixa claro que os contratos eram apenas formais, e que o que acontecia na prática consistia numa série de irregularidades no processo de contratação de moçambicanos para o arquipélago, até dividindo o destino das famílias. Como escreve Nascimento (2005), “ Em Fevereiro de 1929, o Diretor dos NI participou a rejeição na inspeção médica em LM de 45 recrutados. Além dos contratos não estarem em ordem, teria havido fraude porquanto alguns indígenas rejeitados já tinham sido riscados do contrato, ainda assim tendo sido embarcados. Ademais, nenhum indígena trazia a carteira de identificação como determinava a lei e os bilhetes de

\footnotetext{
${ }^{9}$ Fastel Muianga foi entrevistado em São Tomé e Príncipe, nos locais de Riboque Santana, no dia 23/12/2013

10 João Afonso Alfane foi entrevistado em São Tomé e Príncipe, nos locais do lar Santa casa da misericórdia, no dia 02/01/2014
} 
identidade fornecidos pelos agentes de emigração vinham na mão do comissário de bordo." Neste mesmo ano, foram enviados para o arquipélago cerca de 2.008 moçambicanos e repatriados 1.110, segundo Mantero (1954). Os regimes de contrato a que estavam sujeitos, afirma Bragança, remetia-os ao anterior condição de escravos de que tinham saído. "Eram espoliados da sua liberdade, explorados e o "contrato" era quase que sem regresso na maioria dos casos. Uma situação que só viria a ser resolvida com a independência em 1975", embora - como demonstra este trabalho - apenas parcialmente.

3. As condições de vida dos desterrados: período colonial e atualidade. Os "Tongas" (assim eram chamados, em São Tomé, os deportados que mal falavam português) levavam uma vida de escravos, apesar de terem um contrato formalmente assinado. Walekaya, por exemplo, recorda como "o castigo era muito: quando entras no serviço te chicoteiam, mandam-te para o patrão e é chicote também... És escravo mesmo, escravo mesmo...E eu vi meus companheiros a morrer na roça". Como destaca o escritor Albertino Bragança, "entre escravos e contratados a diferença era muito pouca, ou senão nenhuma". ${ }^{11}$ Awaje Chihamati12 disse que "em São Tomé um homem trabalhava a chicote do nascer do sol até pela noite dentro. O capataz gritava: «mais depressa cabrão», e muitos colegas meus morreram a trabalhar. Houve um caso que aconteceu em 1960 na Roça Macaco (uma das grandes extensões de terra cultivada pertencente aos colonos portugueses). Nesta roça, um moçambicano foi atingido durante o trabalho por uma palmeira derrubada pelo vento e ficou preso debaixo do tronco com as costas partidas. Apesar da intensa chuva que se fazia neste dia, fomos chamar o médico, mas este disse que não podia sair à chuva e só chegou de manhã do dia seguinte quando o homem já tinha perdido a vida". As recordações de Rembua vão na mesma direção: "Um homem não é homem em São Tomé. É um animal de trabalho. Só trabalho. Há muito pouco camarada que arranjou mulher porque se ela vier viver para a roça, também tem de trabalhar no campo e ninguém quer ver a sua esposa viver como escrava. Por isso a maior

\footnotetext{
${ }^{11}$ Albertino de Bragança foi entrevistado em São Tomé e Príncipe, nos locais da sua residência, no dia 30/12/ 2013.

${ }^{12}$ Awaje Chihamati foi entrevistado em Maputo pela revista Tempo, 16/02/1975
} 
parte de nós não tem mulher nem filhos". ${ }^{13}$ Braza Afaque recorda o tipo de organização do trabalho implementado nas roças: “Até para beber água, o capataz nos vigiava e contava os minutos pelo relógio. Se um homem ficasse doente o médico não ia-te observar, só te davam uma injeção e mandava retomar o trabalho. Se ele não conseguisse trabalhar seria descontado a semana inteira. (SÁ, 1974). Não era possível denunciar os abusos que os colonos perpetravam contra os trabalhadores. Bragança - na citada entrevista realizada em São Tomé - bem realça que "os contratados estavam entregues a si próprios, e que o setor que lidava com eles era a Curadoria dos Indígena, pelo que era impossível esperar num julgamento imparcial e honesto. Por isso os crimes ficavam sem responsáveis". Tais experiências individuais de milhares de moçambicanos (e não só) confirmam como elas ainda não se tenham transformado numa história coletiva, sendo que os relativos fatos não se tornaram “coisas” (POLLACK, 1992).

Segundo Bragança, "se andarmos pelas terras de São Tomé e Príncipe, pelas roças, encontraremos sítios recônditos que na língua materna são chamados de "Nbilá", que são sepulturas de escravos mortos clandestinamente sem controlo da curadoria que estava do lado dos europeus. Além disso, há um caso de uma cabo-verdiana que assistiu à morte do próprio filho juntamente com o marido e os demais presentes na mata por um capataz europeu, que a queria como mulher. Por incrível que pareça, nenhuma justiça foi feita ao europeu. Este facto serve de chamada de atenção para se compreender que o setor que se responsabilizava por estas pessoas era dominado pelos grandes senhores e pelo poder colonial." A importação de serviçais (NASCIMENTO; DIAS, 1990) tornou-se ocasião de negócio para alguns indivíduos, a um tempo importadores e roceiros. 0 desfasamento entre a produção legislativa sobre a mão-de-obra e a sua aplicação na prática não era questionado (NARTEY, 1986), nem o fato da legislação ter várias vezes sido um recurso para resolver problemas políticos (DUFFY, 1967). Os relatos de maustratos atravessam várias décadas e estão presentes em grande parte das literaturas sobre a mão-de-obra para as culturas de exportação em São Tomé e Príncipe. Compreensão que vai ao encontro da afirmação de Bragança, em que as condições desumanas pelas quais os serviçais passaram e que só tiveram fim com a independência das colónias, ajuda-nos a

\footnotetext{
${ }^{13}$ Rembua foi entrevistado em Maputo pela revista Tempo, 16/02/1975
} 
compreender as diversas roupagens usadas pelos colonos portugueses (RUNGO, 2014). Passar por cima dos mais elementares direitos humanos dos deportados era a única forma para manter a rentabilidade das roças e a exportação dos produtos em altas nos mercados internacionais. Assim conclui Bragança: "Nas plantações todos eram iguais, trabalhavam em condições extremamente péssimas, eram castigados por demostrar cansaço, os anos dos contratos eram renovados na maioria dos casos, sem consentimento do "contratado" e não podiam reclamar sob pena de perder a própria vida. Portanto, estes indivíduos estavam desprovidos de qualquer tipo de direito, ou de condições contratuais." Estas observações vão de encontro aos depoimentos dos entrevistados em São Tomé, com o agravante do sofrimento ter continuado depois da independência.

Além das histórias de sofrimento e de abandono, a miséria também é comum aos poucos sobreviventes residentes no arquipélago. O sentimento de um dia rever seus familiares, sua terra e ter o apoio do Estado Moçambicano, não é comum. Conformismo é a palavra certa para descrever o sentimento desolador de um ser humano que em tom de desabafo refere a morte como a tão sonhada liberdade para o sofrimento que ainda diz viver. "Estão a tratar-me como escravo, mas onde há Deus, ele vai abençoar o seu filho". Palavras de Lia-Lia Tepere ${ }^{14}$ que em troca de um prato de comida, um teto e roupa limpa, presta serviços de zelador em casa de uma cidadã na capital do país. Por não disporem de muita saúde e força para trabalhos pesados, muitos moçambicanos, deportados, desterrados e contratados, prestam pequenos serviços de zelador e guarda como é o caso de Fastel Muianga (Fabião), que vive com a sua família em uma residência pequena no fundo do quintal da igreja onde trabalha. Entre os que constituíram família e continuam nas roças, a situação de miséria é comum.

Com a independência e a nacionalização das roças e distribuição de pequenas parcelas aos antigos serviçais, que não dispunham de capital para investir, afirma Bragança, as roças tornaram-se improdutivas. As pequenas culturas de subsistência que os antigos deportados praticam, não contribuem para a melhoria de vida das suas famílias que dependem, única e exclusivamente, da terra. Abriu-se portanto, com a independência dos

\footnotetext{
14 Lia-Lia Tepere foi entrevistado em São Tomé e Príncipe, nos locais da residência onde trabalha, em São Tomé, no dia 30/12/2013
} 
vários países envolvidos no desterro, uma página histórica nova, pelo menos em termos de possíveis responsabilidades institucionais. Dos três estados eu tiveram indivíduos deportados e ainda residentes em São Tomé, ou seja, Angola, Cabo Verde e Moçambique, só Cabo Verde é que assumiu suas responsabilidades, implementando medidas concretas para apoiar os seus cidadãos, por exemplo investindo na educação dos descentes até a terceira geração. Uma decisão que coloca os antigos contratados cabo-verdianos em melhores condições em relação a angolanos e moçambicanos.

4. O Estado moçambicano diante dos desterrados em São Tomé e Príncipe. Diferentemente de Cabo Verde, Moçambique não assumiu a história e a condição atual dos desterrados, ignorando o seu destino até hoje, e contribuindo de tal forma à obliteração desses fatos. Assim, foi a Santa Casa da Misericórdia em São Tomé e Príncipe que cuidou deles, afirma a Diretora Elsa Viana, ${ }^{15}$ assinalando que o espaço do asilo que ela gere não pode acolher apenas os moçambicanos. "Temos que avaliar a situação destas pessoas e acolher os que estão em pior situação em ralação aos outros. Como podem perceber, existem também angolanos, cabo-verdianos e são-tomenses. Acho que o Estado Moçambicano devia-se interessar destas pessoas e dos seus descendentes". A representação diplomática de Moçambique que responde por São Tomé e Príncipe localiza-se em Angola, o que limita a capacidade de proteção por via consular. O Governo moçambicano nunca garantiu alguma forma de proteção para estes indivíduos, e a pensão que eles recebem do governo são-tomense corresponde aos anos de serviços que prestaram nas roças pós-independência, depois da nacionalização, o que não os dignifica como seres humanos. Outra questão não menos importante refere-se aos valores descontados mensalmente a cada contratado para serem entregues na sua terra de origem no fim do contrato. Os antigos deportados e contratados entrevistados foram unânimes em confirmar que dos 100 escudos que compunham os seus salários, 70 eram postos em caixa para serem recebidos aquando da sua volta para Moçambique, conforme previsto no contrato (NASCIMENTO, 2005). Mas os números de repatriamentos durante o período colonial foram sempre inferiores aos números de moçambicanos que deram entrada no arquipélago (NASCIMENTO, 2005). O último repatriamento de moçambicanos

\footnotetext{
15 Elsa Viana foi entrevistada em São Tomé e Príncipe, nos locais da Santa Casa da Misericórdia, no dia
} $30 / 12 / 2013$. 
para Moçambique ocorreu em 1974, segundo a revista Tempo do mesmo ano, como resultado de negociação entre o governo de transição e o governo colonial. Os valores descontados durante os anos de trabalhos dos que não conseguiram voltar às suas terras de origem, por falta de condições para pagar as passagens, nunca foram pagos e os titulares entregues a própria sorte, como afirma Bragança na entrevista que nos concedeu. A falta de contacto com a terra e consequentemente com os familiares fez com que estas pessoas guardassem uma imagem de um Moçambique que já não existe. $A$ situação atual destas pessoas não tem sido objeto de estudos e muito menos parte da agenda do Estado Moçambicano.

Segundo o antigo Presidente da Comissão Nacional dos Direitos Humanos em Moçambique, Custódio Duma ${ }^{16}$, a essência da pessoa humana está ligada às suas raízes, onde ela encontra a sua cultura, o seu valor pessoal e coletivo. E - consoante a sua opinião - os Governos dos países envolvidos, Moçambique, São Tomé e Príncipe e Portugal, não deviam deixar este assunto esquecido.

O Presidente da Comunidade Muçulmana da Ilha de Moçambique, Hafiz Habdurrazaque ${ }^{17}$, diz que é preciso dar muita atenção a estas pessoas, para que elas sintam o orgulho delas mesmas e, das vidas que lhes foram arrancadas. Braz e Rungo vão mais longe ao afirmar que a questão da deportação de moçambicanos para São Tomé não foi resolvida, nem por parte do Estado Moçambicano, nem por parte do Estado português. Segundo Braz, o assunto deveria ser levantado, primeiro para reconhecer o erro, depois para restituir a humanidade a estas pessoas e seus descendentes. Deixar a questão assim como está sendo feito até hoje significaria reconhecer que não foi perpetrado nenhum crime, ignorando que, pelo contrário, estas pessoas não só tiveram seus direitos básicos violados na altura do colonialismo, mas que, mesmo depois das independências políticas das antigas colónias lusófonas, a sua condição manteve-se muito longe do aceitável. Segundo Rungo, há muito interesse em fazer com que este assunto fique esquecido, sem

\footnotetext{
${ }^{16}$ Custódio Duma foi entrevistado em Maputo, nos locais da Liga dos Direitos Humanos de Moçambique, no dia 15/09/2014

17 Hafiz Habdurrazaque foi entrevistado nos locais na Ilha de Moçambique, nos locais da comunidade Muçulmana, no dia 31/07/ 2014
} 
mexer numa página muito negra da história do colonialismo português, assim como do desempenho quase que completo do Estado Moçambicano (e Angolano) diante desta tragédia coletiva.

Para os São-tomenses que convivem de perto com a situação dos antigos deportados e contratados, como é o caso da Engenheira Conceição $\mathrm{Vaz}^{18}$, o quadro atual mereceria uma atenta consideração por parte dos países de origem: " Moçambique devia olhar para estas pessoas. Assim como Cabo Verde tem feito com os cabo-verdianos, dando-lhes mensalmente uma pensão, levar-Ihes para ver como está a sua terra, rever seus familiares, ter a questão da documentação resolvida mediante a atribuição da nacionalidade aos descendentes que também têm-se beneficiado de bolsas de estudos para fora do país, da mesma forma os Governos de Angola e Moçambique deviam fazer o mesmo, no sentido de dar-lhes uma proteção". Este pensamento é também comungado pelo antigo Chefe de Redação do Jornal Notícias de Moçambique, Alfredo Macaringue ${ }^{19}$, que ao fazer parte de uma delegação de Moçambique que participou numa cimeira da CPLP em 2004, em São Tomé e Príncipe, conheceu Mário Mbebela e reportou em Moçambique a situação deste e dos demais moçambicanos no arquipélago. A única reação que teve foi de pessoas singulares que se prontificaram em pagar a passagem para que este antigo deportado voltasse às suas origens, mas assim como os outros, Mário não possuía documentação, que só viria a ter em 2014 por uma decisão do Governo São-tomense. Nos finais de 2016, Mário morreu na mesma roça onde foi feito escravo, sem nunca ter havido não só o apoio, mas nem o simples bilhete de identidade moçambicano. Um fato que segundo Macaringue, tinha tudo para ter sido tratado de forma diferente, o que não se deu, devido a questões alegadamente burocráticas que travaram todo o processo da ida do Mário a Moçambique. "O Governo Moçambicano devia seguir o exemplo de Cabo Verde", afirmou Macaringue.

Entrevistado em Cabo Vede, o antigo Diretor Geral das Comunidades que responde pelos cabo-verdianos em toda a diáspora, Francisco Carvalho ${ }^{20}$ explica a razão pela qual o

\footnotetext{
${ }^{18}$ Conceição Vaz foi entrevistada em São Tomé, nos locais da sua residência, no dia 30/12/ 2013.

${ }^{19}$ Alfredo Macaringue foi entrevistado, em Maputo, nos locais do Jornal Noticias, no dia 05/02/2-13

${ }^{20}$ Francisco Carvalho foi entrevistado em Cabo Verde-Praia, nos locais da Direção Geral das Comunidade, no dia 08/01/ 2014.
} 
Governo Cabo-verdiano resolveu assumir o problema dos antigos contratados caboverdianos como sendo do Estado. "Nós temos várias preocupações com os caboverdianos na diáspora no sentido de estarem bem integrados no país de acolhimento. Daí que o Governo tem desenvolvido ações, projetos e medidas para melhorar, ou contribuir para que o presente de alguns e o futuro dos descendentes sejam melhores. É extremamente importante fazermos isso enquanto país, porque conseguimos mostrar o nosso lado humano neste processo em que as vítimas são aquelas que foram obrigadas a sair do país. Portanto, é de louvar quando há uma atenção especial que se traduziu, por exemplo, em pensão não contributiva para estas pessoas que saíram do país em períodos complicados e de grandes dificuldades, passaram por um trabalho forçado nas roças sem, em muitos casos, nem ter salários". O compromisso do Estado cabo-verdiano revela portanto a plena consciência de que aquelas estórias individuais deviam constar na história do povo cabo-verdiano, valorizando a sua memória coletiva. Assim Carvalho concluiu: "Este é o melhor caminho para se evitar que aquilo que aconteceu com a geração dos pais não aconteça com a geração dos descendentes e, esta iniciativa estende-se a todos os cabo-verdianos na diáspora a viverem em países como Angola, Guiné Bissau, Moçambique, São Tomé e Príncipe e não só”.

Numa linha diametralmente oposta se coloca o Governo Moçambicano, como confirma um dos homens políticos mais influentes, até hoje, deste país. No papel de antigo Ministro dos Negócios Estrangeiros pós-independência (e depois de Chefe de Estado), Joaquim Chissano, admitiu que a situação dos compatriotas em São Tomé e Príncipe nunca fez parte da agenda política nacional e muito menos da CPLP; entretanto, realçou que os mesmos podem fazer uma exposição para o ministério dos negócios estrangeiros a relatar as suas preocupações. Um tal posicionamento revela, mais uma vez, a distância abismal entre opções da política moçambicana e necessidades concretas que os desterrados até hoje têm. Seria impensável e inviável acreditar que cidadãos idosos, pobres, sem nenhuma formação cultural e sobretudo distantes e sem meios para se dirigir quer a Maputo, quer junto à primeira delegação diplomática moçambicana disponível para São Tomé e Príncipe (Luanda), consigam fazer uma exposição, esperando pela resposta do governo do próprio país. É como dizer que o governo moçambicano 
nunca terá na sua agenda a questão dos desterrados, os quais devem ficar a saber que não poderão contar como apoio do seu governo, mas apenas da caridade e da filantropia da Santa Casa de São Tomé. As afirmações de Chissano se colocam num quadro de conhecimento da questão. O Governo Moçambicano já teve em várias circunstâncias, a oportunidade de se reunir com estas pessoas em São Tomé e Príncipe em ocasião de algumas cimeiras em que se os deportados se fizeram presentes, como afirma Alfredo Macaringue, mas a sua situação nunca foi levada à serio pelas autoridades moçambicanas. Ao contrário da comunidade cabo-verdiana que tem ganho espaço ao longo dos anos e faz-se representar como parte importante na construção da cultura sãotomense, a moçambicana e angolana têm vindo a desaparecer, e a falta de interesse em estudar as dinâmicas sociais deste grupo que também deu seu contributo a esta nação, como afirma Bragança, tem provocado o agravamento da situação. Hafiz assegura ser urgente a corrida contra o tempo no sentido de resgatar destas pessoas uma parte da história de um Moçambique que elas ainda guardam, mas que o país já perdeu e precisa de conhecer.

\section{Considerações Finais}

Os grandes interesses de um capitalismo português ainda fortemente orientado para as plantações de cacau e café de São Tomé e Príncipe fez com que o trabalho forçado e as deportações de trabalhadores formalmente contratados provenientes das outras colónias africanas se alastrasse até ao início dos anos Sessenta.

Mediante uma pesquisa baseada essencialmente num trabalho de terreno de tipo etnográfico junto aos sobreviventes, retornados e a alguns informantes-chave chegou-se à conclusão de que uma das páginas mais sombrias da longa história colonial portuguesa em África iniciou a ser desvendada, recuperando a memória das grandes violações dos direitos humanos a que os desterrados foram submetidos, e de que até hoje continuam vítimas.

Com efeito, mesmo depois da obtenção das independências políticas por parte dos Estados africanos antigas colónias portuguesas, a situação destes indivíduos não 
sofreu alguma melhoria, com a exceção dos deportados cabo-verdianos, cujo Estado assumiu como parte da nação cabo-verdiana e, portanto, suscetíveis de uma ajuda concreta, que abrangeu também os seus descendentes. Muito diferente foi a opção do Estado moçambicano, que nunca assumiu a questão dos "seus" desterrados como relevante do ponto de vista político, abandonando-os por completo à mera assistência da Santa Casa da Misericórdia de São Tomé e Príncipe. A violação dos direitos humanos destes antigos deportados continua até hoje: eles não têm pensão ou subsídio proveniente do Estado moçambicano, não têm documentos do seu Estado de origem, nem tampouco recursos para voltar para Moçambique. Em paralelo, o Estado português também não assumiu a responsabilidade histórica e moral sobre estes deportados, não oferecendo alguma ajuda, a não ser de tipo meramente assistencial em São Tomé e Príncipe. Graças a esta estranha cumplicidade entre o antigo estado colonizador e a sua ex-colónia (Moçambique, mas também Angola), um véu espesso pousou-se por cima da memória dos desterrados, que esta pesquisa procurou desvendar.

A situação "incómoda" em que se encontram o Estado português e o moçambicano diante da trágica situação dos desterrados e diante de responsabilidades históricas bem claras embora diferenciadas fez com que estes preferissem esquecer do assunto, deixando que o Estado de São Tomé e Príncipe o tratasse de forma exclusiva, segundo as suas possibilidades e conveniências.

A pesquisa que resultou deste artigo procurou chamar a atenção sobre uma questão de grave violação dos direitos humanos de um grupo de indivíduos que, de fato, não "pertencendo" a nenhum Estado, ou não sendo reconhecidos por nenhum Estado, continuam a viver em condições misérrimas, quer do ponto de vista material, quer do ponto de vista afetivo, vendo negado até o direito à memória 


\section{Referências}

ALEXANDRE, Valentim. Portugal e a abolição do tráfico de escravos (1834-1851). Análise Social, Lisboa, v. XXVI, n. 111, p. 293-333, 1991.

ALFANE, José Afonso. Entrevista como deportado. Santa Casa da Misericórdia, São Tomé e Príncipe, 02/01/2014

BERNARDO, Maria Ana. $\mathbf{O}$ associativismo agrícola português no Liberalismo e na $\mathbf{1}^{\mathbf{a}}$ República: os sentidos de um percurso, Évora. XXII Encontro da Associação Portuguesa de História Econômica e Social, 16 Novembro 2002. Disponível em: https://dspace.uevora.pt/rdpc/bitstream/10174/4402/1/a\%2520MA\%2520Bernardo.PDF. Acesso em: 12/12/2018

BRAGANÇA, Alberto de. Entrevista como historiador. São Tomé e Príncipe, 30/12/2013.

CABRAL, Manuel Villaverde. Sobre o século XIX português: a transição para o capitalismo. Análise social, Lisboa, v. 12, n. 45, p. 106-126, 1976.

CAHEN, Michel. Seis teses sobre o trabalho forçado no império português continental em África. África, São Paulo, n. 35, p. 129-155, 2015. Disponível em: http://www.revistas.usp.br/africa/article/view/126697/123692. Acesso em: 15/10/2018

CARVALHO, Francisco. Entrevista como antigo Diretor Geral das Comunidades caboverdianas residentes no estrangeiro. Praia, 08/01/2014

CHISSANO, Joaquim Alberto. Entrevista na qualidade de antigo Presidente da República de Moçambique (1986-2004). Maputo, 25/09/2014

CONCEIÇÃO NETO, Maria da. De Escravos a "Serviçais", de "Serviçais" a "Contratados": Omissões, perceções e equívocos na história do trabalho africano na Angola colonial.

Cadernos de Estudos Africanos, Lisboa, v. 33, p. 107-129, 2017.

COOPER, Frederick. Condições análogas à escravidão: imperialismo e ideologia da mãode-obra livre na África. In: ALÉM DA ESCRAVIDÃO: investigações sobre raça, trabalho e cidadania em sociedades pós-emancipação. Rio de Janeiro: Civilização Brasileira, p. 201$270,2005$.

DUARTE, Rosália. Entrevistas em pesquisas qualitativas. Educar em Revista, Rebouças (Paraná), n. 24. 2004. Disponível em:

http://www.scielo.br/scielo.php?script=sci_arttext\&pid=S0104-

40602004000200011\&lng=pt\&tlng=pt. Acesso em: 22/11/2018 
DUMA, Custódio. Entrevista como antigo Presidente da Comissão Nacional dos Direitos Humanos de Moçambique. Maputo, 15/09/2014

GONÇALVES, Ivan Sicca. “Forçar esses rudes negros de África a trabalhar”: trabalho, raça e cidadania na legislação colonial portuguesa (1854-1928). Bilros, Itaperi (Ceará), v. 5, n. 9, pp. 196-220, 2017.

HABDURRAZAQUE, Hafiz. Entrevista como Presidente da Comunidade Muçulmana da Ilha de Moçambique. Ilha de Moçambique, 31/07/2014

HALBWACHS, Maurice. A memória colectiva. São Paulo: Vértice, 1990.

HODGES, Tony; NEWITT, Malyn. São Tomé and Principe: From Plantation Colony to Microstate. Boulder: Westview Press, 1988

JESUS, Adriano de. Entrevista como deportado regressado. Maputo, 10/02/2013

JOBBITT, Rafaela. Medical Practitioners and the Colonial Project: Medicine, Public Hygiene, and the Contexted Recolonization of São Tomé and Príncipe. PHD Thesis in Philosophy. Toronto: York University, 2016. Disponível em:

https://yorkspace.library.yorku.ca/xmlui/bitstream/handle/10315/33416/Jobbitt_Rafaela_20 16_PhD.pdf?sequence=2\&isAllowed=y. Acesso em: 13/09/2018

MACARINGUE, Alfredo. Entrevista como antigo Chefe da Redação do jornal Notícias. Maputo, 05/02/2013

MANTERO, Francisco. A mão-de-obra de S. Tomé e Príncipe. Lisboa: [s.n.],1954

MARQUES, João Pedro. Uma cosmética demorada: as Cortes perante o problema da escravidão (1836-1875). Análise social, Lisboa, v. 36, n. 158-159, p. 209-247, 2001.

MBEBELA, Mário. Entrevista como deportado. Monte Macaco, São Tomé e Príncipe, $30 / 12 / 2013$

MENEZES, Maria Paula. O "indígena" africano e o colono europeu”: a construção da diferença por processos legais. E-Cadernos CES, Coimbra, n. 7, p. 68-93, 2010. Disponível em: http://journals.openedition.org/eces/403. Acesso em: 13/09/2018

MIGUEL, Rui. (2011). O papel do Banco Nacional Ultramarino. BNU Timor - Caixa Geral de Depósitos, Timor Leste. In: https://www.cgd.pt/Institucional/Patrimonio-HistoricoCGD/Estudos/Pages/Abolicao-Escravatura.aspx, Acsso em: 13/09/2018 
MUIANGA, Fastel. Entrevista como deportado, Riboque Santana. São Tomé e Príncipe, $23 / 12 / 2013$

MUYLAERT, Camila Junqueira; SARUBBI, JR, Vicente; GALLO, Paulo Rogério; ROLIM NETO, Modesto Leite; REIS, Alberto Olavo. Narrative interviews: an important resources in qualitative research. Rev. Esc. Enferm., USP, São Paulo, v. 48, n. 2 especial, p. 184-189, 2014. Disponível em: http://www.scielo.br/pdf/reeusp/v48nspe2/0080-6234-reeusp-48nspe2-00184.pdf. Acesso em: 13/09/2018

NASCIMENTO, Augusto. Escravatura, trabalho forçado e contrato em São Tomé e Príncipe nos séculos XIX-XX: sujeição e ética laboral. Africana Studia, Campinas, n. 7, p. 183-217, 2004a.

NASCIMENTO, Augusto. A passagem de coolies por S.Tomé e Príncipe. Arquipélago: História, $2^{\mathrm{a}}$ série, Lisboa, p. 77-112, 2004b.

NASCIMENTO, Augusto. Desterro e contrato: moçambicanos a caminho de S. Tomé e Príncipe (1040 a 1960). Maputo: Ed. AHM, 2005.

NASCIMENTO, Augusto. O contrato de moçambicanos para São Tomé e Príncipe: os ziguezagues da política colonial portuguesa de Novecentos. Metis: história e cultura, Caxias do Sul (Rio Grande do Sul), v. 10, n. 19, p. 43-70, 2011.

NOGUEIRA, Silva Cristina da. Constitucionalismo e império: a cidadania no ultramar português. Lisboa: Almedina, 2009.

OLIVEIRA, Luciana Santos; GUIMARÃES TERRA, Lígia. O desterro da memória e outras invenções in The last flight of the flamingo. Letras \& Letras, Uberlândia (Minas Gerais), v. 31, n.1, p. 216-226, 2015. Disponível em: http://www.scielo.br/pdf/reeusp/v48nspe2/00806234-reeusp-48-nspe2-00184.pdf. Acesso em: 13/10/2018

OLIVEIRA MARTINS, Joaquim Pedro. O Brasil e as colónias portuguesas. Lisboa: Parceria António Maria Pereira Livraria Editora, 1920.

PIMENTEL, Maria do Rosário. A abolição do tráfico de escravos e a ação da diplomacia portuguesa. RIHGB, Rio de Janeiro, v. 174, n. 458, p. 81-108, 2013.

POLLACK, Maurice. Memória, Esquecimento, Silêncio. Estudos históricos, Rio de Janeiro, v. 2, n. 3, p. 3-15, 1989.

POLLACK, Maurice. Memória e identidade social. Estudos históricos, Rio de Janeiro, v. 5, n. 10, p. 200-212, 1992. 
RAMOS, Luís de Oliveira. Em torno do Tratado de 1810, Porto. Comunicação proferida na Universidade do Porto1988. Disponível em:

http://ler.letras.up.pt/uploads/ficheiros/5433.pdf. Acesso em: 13/09/2018

REIS, Jaime. O atraso económico português em perspectiva histórica (1860-1913). Análise social, Lisboa, v. 20, n. 80, p. 7-28, 1984.

RUNGO, Bartolomeu. Entrevista como historiador e arquivista. Maputo, 17/09/2014

SÁ, José. São Tomé, símbolo do colonialismo, começa também a trilhar a via da liberdade e da justiça. Arq. RM, Revista Tempo, Maputo, Ed.13, 1977.

SEIBERT, Gerhard. Camaradas, clientes e compradores: colonialismo, socialismo e democratização em São Tomé e Príncipe. Lisboa: Vega, 2002.

SEIBERT, Gerhard. Colonialismo em São Tomé e Príncipe: hierarquização, classificação e segregação da vida social. Anuário Antropológico, Brasília, v. 40, n. 2, p. 99-120, 2015.

SANTOS, Boaventura de Sousa. Para além do pensamento abissal: das linhas globais a uma ecologia de saberes. Revista crítica de Ciências Sociais, Coimbra, n. 78, p. 3-46. Disponível em:

https://www.ces.uc.pt/myces/UserFiles/livros/147_Para\%20alem\%20do\%2opensamento\%20 abissal_RCCS78.pdf Acesso em: 13/09/2018. DOI: 10.1590/S0101-33002007000300004

SOUZA CORREA, Sílvio Marcus de. History, memory and commemorations: on genocide and colonial past in South West Africa. Revista Brasileira de História, São Paulo, v. 31, n. 61, p. 85-103, 2011.

TEPERE, Lia-Lia. Entrevista como deportado, São Tomé e Príncipe, 30/12/2013

TOMA, Maristela. A pena de degredo e a construção do império colonial português. Métis: história \& cultura, Caxias do Sul (Rio Grande do Sul), v. 5, n. 10, p. 61-76, 2006.

VALÉRIO, Nuno; TJIPILICA, Palmira. Economic activity in the Portuguese Colonial Empire: a factor analysis approach. IEHC Helsinky 2006: Session 103: New Experiences with Historical National Accounts. Paper presented at the 14th International Congress of Economic History, Helsinki, 2006. In: http://www.helsinki.fi/iehc2006/papers3/Valerio.pdf. Acesso em: 13/09/2018

VAZ, Conceição. Entrevista como voluntária da Santa Casa da Misericórdia de São Tomé e Príncipe. São Tomé, 30/12/2013 
VIANA, Elsa. Entrevista como Diretora da Santa Casa da Misericórdia de S. Tomé e Príncipe. São Tomé, 30/12/2013

ZAMPARONI, Valdemir. Da escravatura ao trabalho forçado: teorias e práticas. Africana Studia, Campinas, n. 7, p. 299-325, 2004.

Recebido em 28/05/2018 Aprovado em 30/04/2019

Universidade do Estado de Santa Catarina - UDESC

Programa de Pós-Graduação em História - PPGH

Revista Tempo e Argumento Volume 11 - Número 27 - Ano 2019 tempoeargumento@gmail.com 